\title{
UPAYA MENINGKATKAN HASIL BELAJAR MATEMATIKA DENGAN MODEL PEMBELAJARAN COURSE REVIEW HORAYBERBANTUAN MEDIAKONKRIT PADA KELAS IV SD-N 1KASONGAN LAMA TAHUN PELAJARAN 2016/2017
}

\author{
OLEH : Robiansyah*, Diplan**
}

\begin{abstract}
ABSTRAK
Penelitian ini bertujuan 1) Untuk mengetahui bagaimana aktivitas peserta didik selama proses pembelajaran matematika dengan menggunakan model pembelajaran course review horay berbantuan media konkrit pada kelas IV SDN-1 Kasongan lama. dan 2) Untuk mengetahui apakah ada peningkatan hasil belajar peserta didik pada pembelajaran matematika dengan menggunakan model pembelajaran course review horayberbantuan media konkrit pada kelas IV SDN-1 Kasongan lama.

Jenis penelitian yang digunakan dalam penelitian ini adalah Penelitian Tindakan Kelas (PTK). Dengan jumlah subyek penelitian 20 orang peserta didik yang terdiri dari 10 Lakilaki dan 10 Perempuan yang sekaligus dijadikan sampel penelitian teknik pengumpulan data. Teknik analisis data didasarkan pada hasil siklus tiap proses pembelajaran.

Hasil penelitian menunjukan bahwa 1) Aktivitas peserta didik selama proses pembelajaran matematika lebih aktif dengan menggunakan model pembelajaran course review horayberbantuan media konkritpada kelas IV SDN-1 Kasongan lama. Hal ini dibuktikan dengan hasil penilaian aktivitas peserta didik pada siklus I yaitu 3,36 dan 2) Ada peningkatan hasil belajar peserta didik pada pembelajaran matematika dengan menggunakan model pembelajaran course review horayberbantuan media konkrit pada kelas IV SDN-1 Kasongan lama. Hal ini terlihat dari data hasil belajar peserta didik, pada siklus I hasil belajar peserta didik yaitu $95 \%$.
\end{abstract}

Kata Kunci: Course Review Horay, Media Konkrit, Hasil Belajar Matematika.

\section{PENDAHULUAN}

Pendidikan adalah usaha yang bersifat mendidik, membimbing, membina dan mengarahkan dengan seperangkat ilmu pengetahuan dasar.

Menurut Undang-undang Dasar tahun 2003 sebagai mana tertuang dalam pasal 3 bahwa "Pendidikan Nasional berfungsi membangun kemampuan dan membentuk watak serta peradaban bangsa yang bermartabat dalam rangka mencerdaskan kehidupan bangsa, bertujuan untuk perkembangnya potensi peserta didik agar menjadi manusia yang beriman dan bertaqwa kepada Tuhan Yang Maha Esa, berakhlak mulia, sehat, berilmu, cakaf, kreatif, mandiri dan menjadi warga negara yang demokrasi serta bertanggung jawab”. 
pendidikan merupakan usaha seorang guru atau pendidik dalam mengajar atau mendidik, membimbing, serta membina dan mengarahkan seorang anak yang belum tau menjadi tau yang belum bisa menjadi bisa. Secara umum pendidikan ialah suatu proses yang didalam nya ada unsur-unsur penting yaitu peserta didik, pendidik, tujuan pendidik, alat-alat pendidikan serta lingkungan sekitar dan masyarakat.

Menurut Ngalim Purwanto 2007 Adapun faktor-faktor yang mempengaruhi keberhasilan dalam belajar antara lain : Faktor yang ada pada diri organisme itu sendiri yang kita sebut faktor individual, danFaktor yang ada diluar individu yang kita sebut faktor sosial. Yang termasuk dalam faktor individual ini ialah: faktor kematangan, kecerdasan, latihan, motivasi, dan faktor pribadi. Sedangkan yang termasuk faktor sosial antara lain faktor keluarga/keadaan rumah tangga, guru dan cara mengajar nya alat-alat yang dipergunakan dalam belajar mengajar, lingkungan dan kesempatan yang tersedia,dan motivasi sosial.

Pelajaran matimatika sangat penting dalam kehidupan sehari-hari, karena dapat membantu ketajaman berpikir secara logis (masuk akal) serta membantu memperjelas dalam menyelesaikan permasalahan. Rendah nya penguasaan siswa terhadap materi pelajaran terutama pelajaran matematika. Kurang mampunya siswa dalam memahami materi pelajaran matematika ini terlihat dari rendahnya prestarsi belajar matematika yang dicapai oleh siswa. Hal ini dibuktikan dengan rata-rata hasil belajar siswa yang diperoleh melalui nilai tugas harian yang masih banyak dibawah KKM 55. Salah satu faktor yang mempengaruhi prestasi belajar siswa adalah minat serta model pembelajaran dan penggunaan media pembelajaran yang epektif untuk mendorong minat belajar siswa tersebut.

Untuk mengetahui permasalahan diatas dan guna mencapai tujuan pendidikan secara maksimal, peran guru sangat penting dan diharapkan guru memiliki cara/model mengajar yang baik dan mampu memilih model yang tepat dan sesuai dengan kompetensikompetensi dasar mata pelajaran yang ingin dicapai.

Berdasarkan hasil observasi hari rabu tanggal 04 januaru 2017 pukul 07 08:45 yang dilakukan pada kelas IV SDN-1 Kasongan Lama pada pembelajaran Matematika dengan guru kelas, ada beberapa permasalahan yang ditemui ketika peniliti melakukan observasi yaitu, Ketika guru melakukan tanya jawab kepada peserta didik, mereka terlihat diam dan tidak mau bersuara serta kelihatan tidak ada yang paham dengan apa yang dijelaskan oleh guru didepan .

Pembelajaran matematika yang diajarkan hanya cenderung berpusat pada guru, hal ini terlihat lebih aktifnya guru menjelaskan materi ajar kepada siswa. Itupun model yang banyak dipakai oleh guru banyak model ceramah serta sering pemberian tugas secara acak oleh guru dan memberikan contoh soal yang terlalu sulit dimengerti oleh peserta didik 
sehingga membuat pemlajaran menjadi monoton tidak menarik sama sekali.

Peserta didik masih belum obtimal dalam mngikuti pembelajaran yang berlangsung, dilihat dari ketika pembelajaran berlangsung peserta didik cenderung asik main dengan teman sebangku dan tidak memperhatikan guru didepan.

Guru kurang memanfaatkan media sederhana yang ada di sekitar ruangan kelas sehingga pembelajaran yang berlangsung kurang melibatkan siswa atau peserta didik.Untuk itu diperlukan suatu upaya untuk meningkatkan mutu pendidikan dan pengajaran matematika. Melalui sebuah metode dan media yang menarik bagi peserta didik supaya pembelajaran menjadi lebih menarik dan bisa melibatkan peserta didik langsung serta peserta didik tidak cenderung bosan dengan pelajaran yang di ajarkan.

Maka dari itu untuk memahami persoalan yang berkembang di atas yang berkaitan dengan metode dan media yang menarik bagi peserta didik dalam pembelajaran matematika. Peneliti tertarik ingin mengangkat sebuah judul "UPAYA MENINGKATKAN HASIL BELAJAR MATEMATIKA DENGAN MODEL PEMBELAJARAN COURSE REVIEW HORAY BERBANTUAN MEDIA KONKRIT PADA KELAS IV SD-N 1KASONGAN LAMA TAHUN PELAJARAN 2016/2017','

METODE PENELITIAN

Robiansyah* Mahasiswa FKIP UM Palangkaraya

Diplan** Dosen Universitas Muhammadiyah Palangkaraya 
matematika. Artinya hanya ada sekitar $35 \%$ Peserta didik yang tuntas dengan nilai rata-rata 42.

\section{Siklus I}

Dalam pelaksanaan tindakan kelas ini dilakukan secara bertahap yaitu dengan tahapan I siklus. Tiap-tiap siklus terdiri dari tahapan Perencanaan, pelaksanaan tindakan, observasi, dan refleksi. Dalam pelaksanaan tindakan siklus I, pembelajaran dilakukan dengan model pembelajaran course review horay.

Berdasarkan lembar observasi aktifitas peserta didik serta guru dan hasil tes peserta didik pada tindakan siklus I yaitu mendapat nilai 3,36 untuk aktifitas peserta didik sedangkan aktivitas guru yaitu 3,6 dan untuk tes hasil belajar peserta didik yaitu dengan nilai rata-rata peserta didik memperoleh nilai rata-rata 51 dan hasil ketuntasan peserta didik hanya $40 \%$. Nilai ini sangat jauh dari nilai klasikal yang ditentukan yakni $85 \%$. Kemudian pada sikus I niai rata-rata peserta didik meningkat 86 dan hasi beajar peserta didik meningkat yakni $95 \%$ ini sudah mencapai kriteria ketuntasan yang ditentukan yakni $85 \%$. Berdasarkan hasil tes tersebut dapat dilihat adanya peningkatan kemampuan penjumlahan bilngan bulat dengan garis bilangan peserta didik pada tindakan siklus I dibandingkan kemampuan peserta didik sebelum dilakukan tindakan. dan proses tindakan diberhentikan pada siklus I dan peneliti sangat puas dengan hasil diperoleh.

\section{SIMPULAN}

Berdasarkan hasil penelitian yang telah dibahas maka dapat disimpulkan beberapa hal yaitu:

1. Aktifitas belajar Matematika pada kelas IV SDN-1 Kasongan Lama dengan menggunakan model pembelajaran Course Review Horay berbantuan mediakonkrit masuk dalam kategori Baik.Hal ini dapat dilihat berdasarkan hasil pengamatan dari pengamat I dan pengamat II, dimana pada siklus I aktivitas peserta didik dengan nilai rata-rata yaitu 3,36 dengan kategori baik.

2. Ada peningkatan hasil belajar pada kelas IV SDN-1 Kasongan Lama dengan menggunakan model pembelajaran Course Review Horay berbantuan mediaKonkrit.Hal ini telihat dari hasil belajar peserta didik, pada siklus I rata - rata hasil belajar peserta didik yaitu 86 dan ketuntasan secara klasikalnya yaitu 95\%. Adapun standar ketuntasan yang ditentukan sekolah untuk pelajaran matematika yaitu 55 .

\section{DAFTAR PUSTAKA}

Purwanto.Ngalim. 2007. Pisikologi

Pendidikan. Bandung : PTREMAJA

ROSDAKARYA.

Undang-undang RI No. 20 Tahun 2003.

Tentang Sistem Pendidikan Nasional, Bandung: Citra Umbara 2003 